\title{
RESISTANCE TO ACCASE INHIBITORS IN Eleusine indica FROM BRAZIL INVOLVES A TARGET Site MUTATION ${ }^{1}$
}

\author{
Resistência aos Inibidores de ACCase em Eleusine indica do Brasil Envolve uma Mutação na \\ Enzima Alvo
}

\author{
OSUNA, M.D. ${ }^{2}$, GOULART, I.C.G.R. ${ }^{3}$, VIDAL, R.A. ${ }^{3}$, KALSING, A. ${ }^{3}$, RUIZ SANTAELLA, J.P. ${ }^{4}$, and \\ DE PRADO, R. ${ }^{4}$
}

\begin{abstract}
Eleusine indica (goosegrass) is a diploid grass weed which has developed resistance to ACCase inhibitors during the last ten years due to the intensive and frequent use of sethoxydim to control grass weeds in soybean crops in Brazil. Plant dose-response assays confirmed the resistant behaviour of one biotype obtaining high resistance factor values: 143 (fenoxaprop), 126 (haloxyfop), 84 (sethoxydim) to 58 (fluazifop). ACCase in vitro assays indicated a target site resistance as the main cause of reduced susceptibility to ACCase inhibitors. PCR-generated fragments of the ACCase CT domain of the resistant and sensitive reference biotype were sequenced and compared. A point mutation was detected within the triplet of aspartate at the amino acid position 2078 (referred to EMBL accession no. AJ310767) and resulted in the triplet of glycine. These results constitute the first report on a target site mutation for a Brazilian herbicide resistant grass weed.
\end{abstract}

Keywords: goosegrass, cross-resistance, enzyme, PCR, herbicide.

RESUMO - Eleusine indica (ELEIN) é uma espécie monocotiledônea, diploide. No Brasil, ela desenvolveu resistência aos inibidores da ACCase durante os últimos dez anos, devido ao uso intensivo e frequente desses graminicidas para controlar plantas daninhas em lavouras de soja. Experimentos de dose-resposta realizados com a planta confirmaram a resistência de um biótipo. Houve elevada tolerância aos herbicidas, com fatores de resistência da ordem de 143 (fenoxaprop), 126 (haloxyfop), 84 (sethoxydim) e 58 (fluazifop). Ensaios com a enzima ACCase in vitro indicaram a insensibilidade desta como a principal causa de suscetibilidade reduzida a esses herbicidas. Fragmentos de PCR gerados do dominio CT da enzima ACCase dos biótipos resistente e sensivel de referência foram sequenciados e comparados. Foi detectada uma mutação dentro do tripleto de asparagina na posição do aminoácido 2078 (referente ao acesso número AJ310767 no EMBL), que resultou no tripleto de glicina. Esses resultados constituem o primeiro caso de uma mutação em ACCase em uma espécie daninha gramínea do Brasil.

Palavras-chave: capim-pé-de-galinha, resistência cruzada, enzima, PCR, herbicidas.

\section{INTRODUCTION}

Eleusine indica Gaertn (goosegrass) is a species originated from Asia and represents one of the most important grass weeds in crops from tropical and temperate regions of the world. It is an annual species and the average production per plant is approximately 40,000

Recebido para publicação em 10.5.2012 e aprovado em 10.7.2012.

2 Centro de Investigacion “Finca La Orden-Valdesequera”, Departamento de Hortofruticultura, 06187 Guadajira, Badajoz (Spain); ${ }^{3}$ Universidade Federal do Rio Grande do Sul, Faculdade de Agronomia, Dep. de Plantas de Lavoura, Av. Bento Gonçalves, 7712, Porto Alegre-RS, Brasil; ${ }^{4}$ Universidad de Córdoba, Dep. de Química Agrícola, 14004 Córdoba (Spain). 
seeds when in pure stands (Kissman \& Groth, 1991).The soybeans mass was reduced 12,19 and $25 \%$ due to root, shoot, and both shoot/ root competition with $E$. indica, respectively (Xia et al., 1997).

During the past three decades grass weeds were controlled in soybean predominantly with herbicides inhibitors of the enzyme acetylCoA carboxylase (ACCase). The herbicides that affect ACCase enzyme include the chemistries aryloxyphenoxypropionates (AOPP), cyclohexanediones (CHD), and pyrazolines. In Brazil, an E. indica biotype was diagnosed with resistance to this group of herbicides in 2005 in soybean crops located in the central part of Mato Grosso state (Vidal et al., 2006).

Weed resistance to herbicides is defined as the inheritable ability of individuals to survive after repeated use of a compound that controls the original population (Gherekhloo et al., 2012). Since 1975, about ten new herbicide resistant biotypes are documented yearly. Cross-resistance is referred as resistance to several herbicides that affect one target enzyme, and usually is endowed by a single gene (Délye, 2005). Herbicide crossresistance on many plant species have been documented due to ACCase enzymes with amino acid substitutions at the positions: 1781 (White et al., 2005), 1999 (Liu et al., 2007); 2027 (Délye et al., 2003; Liu et al., 2007; Gherekhloo et al., 2012); 2041 (Délye et al., 2003; Zhang \& Powles, 2006; Liu et al., 2007); 2078 (Délye et al., 2005; Kaundun, 2010; Hochberg et al., 2009); at 2088 (Yu et al., 2007), and 2096 (Délye et al., 2005). The choice of herbicide to control a resistant population is complicated by the fact that the specific amino acid substitutions in one enzyme may give different patterns of cross resistance to the different herbicides that affect it (Powles \&Yu, 2010).

This work was designed to test the hypotheses that a) there is cross-resistance of $E$. indica to several ACCase inhibitors, b) the ACCase enzyme is insensitive to this group of herbicides on this biotype, and c) a mutation on the ACCase gene is the molecular basis of the resistance on a population from Brazil.

\section{MATERIALS AND METHODS}

\section{Seed source}

Eleusine indica seeds from two biotypes were collected from at least 1000 plants. The biotype suspect of resistance to ACCase inhibitors (R) was collected from plants growing on a farm located in the county of Lucas do Rio Verde, in Mato Grosso state, Brazil. This farm has been cropped with soybeans during the last 20 years with at least one postemergence spray of sethoxydim at $230 \mathrm{~g} \mathrm{ha}^{-1}$ per year. The biotype susceptible to herbicides (S), used as a reference population, was collected in the state of São Paulo, Brazil, in places never treated with herbicides for the past 15 years.

\section{Dose-response experiments at plant level}

Dose-response curves were generated in eight experiments to evaluate the resistance to several ACCase inhibitors (butroxydim, clethodim, cyhalofop, fenoxaprop, fluazifop, haloxyfop, quizalofop, sethoxydim) on both biotypes. Seeds of $E$. indica from each biotype were placed in a $2.0 \mathrm{~L}$ capacity trays containing potting $\operatorname{mix}(50 \%$ soil / $50 \%$ sand $(\mathrm{v} / \mathrm{v}))$ as substrate. The trays were kept irrigated and when seedlings were at the two-leaf growth stage they were transplanted to $0.3 \mathrm{~L}$ pots with potting mix as already described. Plants were kept on a greenhouse with day/night temperature of $29 \pm 5$ e $20 \pm 6{ }^{\circ} \mathrm{C}$, respectively. When plants were at the six to eight-leaf growth stage, the herbicides were sprayed with a $\mathrm{CO}_{2}$ hand-held sprayer delivering a total of $220 \mathrm{~L} \mathrm{ha}^{-1}$ at $200 \mathrm{kPa}$.

A hierarchic factorial arrangement of the treatments was used for each experiment, using a completely random design and three replicates for each treatment. The first factor was the biotype (R and S); and the second factor was the herbicide rates, which included 0,25 , $35,50,70,100,200,400,800,1,600$, and $3,200 \%$ of the labeled rate. The herbicide labeled rates were: butroxydim $375 \mathrm{~g} \mathrm{ha}^{-1}$, clethodim $108 \mathrm{~g} \mathrm{ha}^{-1}$, cyhalofop-butyl $57 \mathrm{~g} \mathrm{ha}^{-1}$, fluazifop-P-butyl $125 \mathrm{~g} \mathrm{ha}^{-1}$, haloxyfop-Pmethyl $60 \mathrm{~g} \mathrm{ha}^{-1}$, sethoxydim $230 \mathrm{~g} \mathrm{ha}^{-1}$. Visual evaluations of plant injury were collected at 
21 days after herbicide spray (DAT), using the 0 to 100 scale described by Frans et al. (1986), where 0 represents no effect and 100 represents plant death.

Data were subjected to the analysis of variance (ANOVA). When significant herbicide rate $\mathrm{x}$ biotype interaction was detected, curve fitting techniques were used to adjust doseresponse curves for each biotype. The data was fitted to a nonlinear, log-logistic threeparameters regression model

$$
\left.\mathrm{Y}=\mathrm{a} /\left[1+\left(\mathrm{x} / \mathrm{ED}_{50}\right)^{\mathrm{b}}\right]\right\} \text {, }
$$

where $\mathrm{Y}$ is the dependent variable (expressed as 100 - plant injury), a corresponds to the upper asymptote; $b$ is the slope of the curve; and $\mathrm{ED}_{50}$ is the effective dose needed for $50 \%$ plant injury. The resistant factor (RF) was calculated by dividing the $\mathrm{ED}_{50}$ of the resistant biotype by the $\mathrm{ED}_{50}$ of the susceptible biotype.

\section{ACCase enzyme purification and assay}

The ACCase enzyme was isolated using procedures adapted from (De Prado et al., 2000). Leaves ( $6 \mathrm{~g}$ fresh weight) of R and S biotypes of $E$. indica were harvested from plants in 3-4 leaf stages and ground in liquid $\mathrm{N}_{2}$ in a mortar and then added to $24 \mathrm{~mL}$ of extraction buffer [0.1 M Hepes-KOH (pH7.5), 0.5 M glycerol, 2 mM EDTA, and $0.32 \mathrm{mM} \mathrm{PMSF}$. The homogenate was mixed for 3 min with a magnetic stirrer and filtered sequentially through four layers of cheesecloth and two of Miracloth (Miracloth, Calbiochem, San Diego, CA). The crude extract was centrifuged $\left(24,000 \mathrm{~g}, 30 \mathrm{~min}, 4^{\circ} \mathrm{C}\right)$. The supernatant was fractioned with ammonium sulfate and centrifuged $(12,000 \mathrm{~g}, 10 \mathrm{~min}$, $4{ }^{\circ} \mathrm{C}$ ). Material precipitating between 35 and $45 \%\left(\mathrm{NH}_{4}\right)_{2} \mathrm{SO}_{4}$ saturation was resuspended in $1 \mathrm{~mL}$ of $\mathrm{S} 400$ buffer $[0.1 \mathrm{M}$ Tricine-KOH (pH 8.3), $0.5 \mathrm{M}$ glycerol, $0.05 \mathrm{M} \mathrm{KCl}, 2 \mathrm{mM}$ EDTA, and $0.5 \mathrm{mM}$ DTT]. The clarified supernatant was applied to a desalting column (PD-10 columns, Sephadex G-25 M, Amersham Biosciences AB, SE-751 84, Uppsala, Sweden), previously equilibrated with $25 \mathrm{~mL}$ of $\mathrm{S} 400$ buffer. ACCase enzyme was eluted from the column in $2 \mathrm{~mL}$ of $\mathrm{S} 400$ buffer.

The enzyme activity was assayed by measuring the ATP-dependent incorporation of $\mathrm{NaH}\left[{ }^{14} \mathrm{C}\right] \mathrm{O}_{3}$ into $\left[{ }^{14} \mathrm{C}\right]$ malonyl-CoA. Assays were conducted in $7 \mathrm{~mL}$ scintillation vials containing $0.1 \mathrm{M}$ Tricine- $\mathrm{KOH}$ ( $\mathrm{pH}$ 8.3), $0.5 \mathrm{M}$ glycerol, $0.05 \mathrm{M} \mathrm{KCl}, 2 \mathrm{mM}$ EDTA, $0.5 \mathrm{mM}$ DTT, $1.5 \mathrm{mM} \mathrm{MgCl}_{2}, 15 \mathrm{mM} \mathrm{NaH}\left[{ }^{14} \mathrm{C}_{\mathrm{O}} \mathrm{O}_{3}\right.$ (1.22 MBq $\left.\mu \mathrm{mol}^{-1}\right), 50 \mu \mathrm{L}$ of enzyme fraction, $5 \mathrm{mM}$ acetyl-CoA in a final volume of $0.2 \mathrm{~mL}$. The activity was assayed for $5 \mathrm{~min}$ at $34^{\circ} \mathrm{C}$, and the reaction was stopped after 5 min by adding $30 \mu \mathrm{L}$ of $4 \mathrm{~N} \mathrm{HCl}$. A piece of filter paper was added to the reaction vial, and samples were dried at $40^{\circ} \mathrm{C}$ under a stream of air. After drying, ethanol/water $(1 / 1, \mathrm{v} / \mathrm{v}, 0.5 \mathrm{~mL})$ was added to the vial, followed by the addition of $5 \mathrm{~mL}$ of scintillation cocktail (Redy safe, Beckman Instruments Inc.). Radioactivity was determined by LCC. Background radioactivity measured as acid-stable counts (dpm) in the blank treatment, which consisted of all ingredients of the reaction but acetyl-CoA, was subtracted from each treatment. One unit of ACCase activity was defined as $1 \mu \mathrm{mol}$ malonyl CoA formed $\mathrm{min}^{-1}$. Herbicide concentrations resulting in a $50 \%$ ihibition of enzyme activity $\left(\mathrm{EC}_{50}\right)$ were determined in crude extracts. Herbicide and range of concentrations tested consisted of: cyhalofop acid from 0 to $300 \mu \mathrm{M}$, fenoxaprop acid from 0 to $30 \mu \mathrm{M}$, sethoxydim from 0 to $2000 \mu \mathrm{M}$, and tepraloxydim from 0 to $30 \mu \mathrm{M}$. Experiments were repeated three times. Data were submitted to analysis of variance and fitted to the logistic equation as described before.

\section{Molecular studies}

Total genomic DNA was extracted from fresh plants at the four-leaf stage by using the Qiagen DNA Extraction Kit from $100 \mathrm{mg}$ of frozen leaf material. In all cases, DNA was quantified with NanoDrop then immediately used for PCR reactions or stored at $-80{ }^{\circ} \mathrm{C}$ until its use.

Primers were designed to amplify regions in the CT domain know to be involved in sensitivity to ACCase herbicides. Two sets of primers (Table 1) covering all known mutation sites, were designed based on the chloroplastic ACCase sequences of other grass weeds, Alopecurus myosuroides (accession no. AJ632096), Lolium rigidum (AY995232), Avena fatua (AF231335) and Phalaris paradoxa (AM745339) (Table 1). Ten individual plants from each population were genotyped. 
Table 1 - Primers designed to amplify regions in the CT domain know to be involved in sensitivity to ACCase herbicides

\begin{tabular}{|l|l|}
\hline \multicolumn{1}{|c|}{ Primer } & \multicolumn{1}{c|}{ Sequence } \\
\hline ELEIN_1781F & GCGTGCTGCTGGGCTGAAT \\
\hline ELEIN_1781R & CCGGTCAAAATAATGGGCTGGTC \\
\hline ELEIN_2027_f & AATGGCTGGGTGGTATGTTTGAC \\
\hline ELEIN_2027_r & ATCCTCCGCCGTAATCTCTTGTAG \\
\hline
\end{tabular}

PCR was conducted in a $25 \mu \mathrm{L}$ volume that consisted of about $300 \mathrm{ng}$ of genomic DNA, $0.5 \mu \mathrm{M}$ of each primer, and $12.5 \mu \mathrm{L}$ of $2 \mathrm{X}$ GoTaq Green Master mix (Promega). The PCR was run in an Eppendorf Master Gradient Thermo cycler Model 96 programmed for an initial denaturation step of $94^{\circ} \mathrm{C}$ of $4 \mathrm{~min}$ followed by 35 cycles of $30 \mathrm{~s}$ at $94{ }^{\circ} \mathrm{C}, 30 \mathrm{~s}$ at $58^{\circ} \mathrm{C}$ and $30 \mathrm{~s}$ at $72{ }^{\circ} \mathrm{C}$. A final extension step for $5 \mathrm{~min}$ at $72{ }^{\circ} \mathrm{C}$ was also included. The PCR products were directly purified or purified from agarose gel with Wizard SV gel and PCR Clean-up system (Promega), and were sequenced by the central facilities of the University of Córdoba.

\section{RESULTS AND DISCUSSION}

\section{Dose-response experiments at plant level}

For all herbicides tested, a significant $(\mathrm{P}<0.01)$ biotype by rate interaction was detected with the F test (data not shown). The data of plant injury from the R and $\mathrm{S}$ biotypes were fitted to the logistic dose-response curves with significant $(\mathrm{P}<0.01)$ level of significance of the nonlinear model (Table 2). For all herbicides, and for both biotypes, with the increase of the herbicide rate the level of plant injury increased following a typical sigmoidal dose-response curve. Cross resistance to ACCase inhibitor herbicides was confirmed in the $E$. indica biotype originated from Mato Grosso.

For the resistant biotype, the herbicide rate necessary to promote $50 \%$ plant injury $\left(\mathrm{ED}_{50}\right)$ ranged from $185 \mathrm{~g} \mathrm{ha}^{-1}$, for haloxyfop-Pmethyl, to $>1,800 \mathrm{~g} \mathrm{ha}^{-1}$, for cyhalofop-butyl (Table 2). The $\mathrm{ED}_{50}$ determined for the resistant $E$. indica biotype with the herbicides clethodim and cyhalofop-butyl was superior to the highest herbicide rate tested in the experiments, indicating that at the tested rates the level of plant injury had not reached 50\%.

For the susceptible biotype, however, the $\mathrm{ED}_{50}$ ranged from $11 \mathrm{~g} \mathrm{ha}^{-1}$, for haloxyfop-Pmethyl, to $190 \mathrm{~g} \mathrm{ha}^{-1}$, for butroxydim (Table 2). This indicates that for all herbicides, the level of plant injury evaluated on the susceptible biotype was high at very low herbicide rates.

The RF calculated for the $R$ biotype indicates three group of cross-resistance. A low level resistance ( 3 to 6) for butroxydim and fluazifop-P-butyl; a medium level of resistance (10 to 16) for clethodim and haloxyfop-P-methyl; and a high level of resistance $(>20)$ for cyhalofop-butyl and sethoxydim (Table 2).

\section{ACCase enzyme assay}

Two herbicides representing the AOPP and two representing the CHD were used to test the sensitivity of the ACCase enzyme of both $\mathrm{R}$ and $\mathrm{S}$ biotypes. For all herbicides tested, a significant $(\mathrm{P}<0.01)$ biotype by concentration interaction was detected with the $\mathrm{F}$ test (data not shown). The data of plant injury from the $\mathrm{R}$ and $\mathrm{S}$ biotypes were fitted to the logistic dose-response curves with significant $(\mathrm{P}<0.01)$ level of significance of the nonlinear model (Table 3). For all herbicides, and for both biotypes, with the increase of the herbicide rate the activity of the ACCase enzyme decreased following a typical sigmoidal doseresponse curve.

For the resistant biotype, the herbicide concentration necessary to promote $50 \%$ enzyme inhibition $\left(\mathrm{EC}_{50}\right)$ ranged from $12 \mu \mathrm{M}$ for fenoxaprop acid to $1169 \mu \mathrm{M}$ for sethoxydim (Table 3). For the susceptible biotype the $\mathrm{EC}_{50}$ ranged from $0.13 \mu \mathrm{M}$ for fenoxaprop acid to $104 \mu \mathrm{M}$ for sethoxydim (Table 3). Like the results at the plant level, the ACCase enzyme activity on the susceptible $E$. indica biotype was affected significatively at very low herbicide concentrations.

\section{Molecular studies}

Ten individuals of each population were sequenced. Then, the sequences were aligned to each other and to the chloroplastic 
Table 2 - Parameters of the equation ${ }^{1 /}$ used to calculate the herbicide dose required for $50 \%$ plant injury $\left(\mathrm{ED}_{50}\right)$ of resistant $(\mathrm{R})$ and susceptible (S) biotypes of Eleusine indica

\begin{tabular}{|c|c|c|c|c|c|c|c|}
\hline Herbicide $^{\underline{2} /}$ & Biotype & $\mathrm{a}$ & $\mathrm{b}$ & $\mathrm{ED}_{50} \pm \mathrm{SE}^{\underline{3} /}$ & Pseudo $r^{24}$ & $\mathrm{P}^{\frac{5 /}{1}}$ & $\mathrm{RF}^{6 /}$ \\
\hline \multirow{2}{*}{$\mathrm{BU}$} & $\mathrm{R}$ & 99.88 & 1.84 & $432.36 \pm 68.45$ & 0.93 & $<0.01$ & 2.3 \\
\hline & $S$ & 93.62 & 1.97 & $190.36 \pm 54.25$ & 0.79 & 0.01 & - \\
\hline \multirow{2}{*}{$\mathrm{CB}$} & $\mathrm{R}$ & 99.75 & 0.98 & $3027.22 \pm 229.78$ & 0.98 & $<0.01$ & 94.1 \\
\hline & $S$ & 99.78 & 5.68 & $32.17 \pm 3.41$ & 0.85 & 0.02 & - \\
\hline \multirow{2}{*}{$\mathrm{CL}$} & $\mathrm{R}$ & 100.89 & 1.06 & $737.10 \pm 184.17$ & 0.80 & 0.01 & 10.7 \\
\hline & $\mathrm{S}$ & 97.59 & 4.51 & $68.70 \pm 9.55$ & 0.81 & 0.01 & - \\
\hline \multirow{2}{*}{ FB } & $\mathrm{R}$ & 97.55 & 2.47 & $202.22 \pm 8.47$ & 0.98 & $<0.01$ & 6.7 \\
\hline & $\mathrm{S}$ & 100.00 & 58.41 & $30.22 \pm 5.93$ & 0.99 & $<0.01$ & - \\
\hline \multirow{2}{*}{$\mathrm{HM}$} & $\mathrm{R}$ & 102.40 & 0.96 & $185.31 \pm 50.38$ & 0.86 & $<0.01$ & 16.8 \\
\hline & $\mathrm{S}$ & 100.02 & 2.73 & $11.02 \pm 1.74$ & 0.98 & $<0.01$ & - \\
\hline \multirow{2}{*}{ SE } & $\mathrm{R}$ & 102.57 & 3.07 & $521.20 \pm 21.80$ & 0.99 & 0.01 & 21.5 \\
\hline & $S$ & 99.99 & 1.58 & $24.20 \pm 3.56$ & 0.99 & $<0.01$ & - \\
\hline
\end{tabular}

${ }^{1 /}$ Logistic equation $\left.\mathrm{Y}=\mathrm{a} /\left[1+\left(\mathrm{x} / \mathrm{ED}_{50}\right)^{\mathrm{b}}\right]\right\}$, where $\mathrm{Y}$ is the percentage of plant injury, $\mathrm{x}$ (independent variable) is the herbicide rate (g ha $\left.{ }^{-1}\right)$, $a$ is the the upper asymptote, $b$ is the slope of the line, and $\mathrm{ED}_{50}$ is the effective rate required for $50 \%$ plant injury. Data were pooled and fitted to nonlinear regression model. Data are means of four replicates. ${ }^{2} / \mathrm{BU}=$ butroxydim, $\mathrm{CB}=$ cyhalofop-butyl, $\mathrm{CL}=$ clethodim, $\mathrm{FB}=$ fluazifopP-butyl, HM=haloxyfop-P-methyl, SE=sethoxydim. ${ }^{3 /} \mathrm{SE}=$ standard error of the value. ${ }^{4 /}$ Approximate coefficient of determination of nonlinear models with a defined intercept calculated as pseudo $r^{2}=1$ - (sums of squares of the regression/corrected total sums of squares). ${ }^{5 /}$ Probability level of significance of the nonlinear model. ${ }^{6} \mathrm{RF}=$ resistant factor $=\mathrm{ED}_{50}$ of resistant $/ \mathrm{ED}_{50}$ of susceptible biotype.

Table 3 - Parameters of the equation ${ }^{1 /}$ used to calculate the herbicide concentration required for $50 \%$ reduction of ACCase activity $\left(\mathrm{EC}_{50}\right.$ ) of resistant $(\mathrm{R})$ and susceptible $(\mathrm{S})$ biotypes of Eleusine indica

\begin{tabular}{|c|c|c|c|c|c|c|c|}
\hline Herbicide $^{2 /}$ & Biotype & \multicolumn{1}{c|}{$\mathrm{a}$} & $\mathrm{b}$ & $\mathrm{ED}_{50} \pm \mathrm{SE}^{3 /}$ & Pseudo $^{2}{ }^{4 /}$ & $\mathrm{P}^{\frac{5}{}}$ & $\mathrm{RF}^{6 /}$ \\
\hline \multirow{2}{*}{$\mathrm{CA}$} & $\mathrm{R}$ & 100.26 & 1.01 & $112.4 \pm 1.4$ & 0.99 & $<0.01$ & 55.4 \\
\cline { 2 - 9 } & $\mathrm{S}$ & 99.91 & 0.56 & $2.03 \pm 0.1$ & 0.99 & $<0.01$ & - \\
\hline \multirow{2}{*}{$\mathrm{FA}$} & $\mathrm{R}$ & 98.42 & 1.07 & $12.3 \pm 0.9$ & 0.99 & $<0.01$ & 94.5 \\
\cline { 2 - 9 } & $\mathrm{S}$ & 100.00 & 0.52 & $0.1 \pm 0.04$ & 0.99 & $<0.01$ & - \\
\hline \multirow{2}{*}{$\mathrm{SE}$} & $\mathrm{R}$ & 100.70 & 0.58 & $1168.9 \pm 423.3$ & 0.96 & $<0.01$ & 11.2 \\
\cline { 2 - 9 } & $\mathrm{S}$ & 11.10 & 0.85 & $104.7 \pm 10.9$ & 0.99 & $<0.01$ & - \\
\hline \multirow{2}{*}{$\mathrm{TP}$} & $\mathrm{R}$ & 99.69 & 2.31 & $23.0 \pm 0.1$ & 0.99 & 0.01 & 15.26 \\
\cline { 2 - 9 } & $\mathrm{S}$ & 99.71 & 1.22 & $1.5 \pm 0.05$ & 0.99 & $<0.01$ & - \\
\hline
\end{tabular}

${ }_{1}^{1 /}$ Logistic equation $\left.\mathrm{Y}=\mathrm{a} /\left[1+\left(\mathrm{x} / \mathrm{EC}_{50}\right)^{\mathrm{b}}\right]\right\}$, where $\mathrm{Y}$ is the percentage of enzyme inhibition, $\mathrm{x}$ (independent variable) is the herbicide concentration $(\mu \mathrm{M})$, $\mathrm{a}$ is the the upper asymptote, $\mathrm{b}$ is the slope of the line, and $\mathrm{EC}_{50}$ is the effective concentration required for $50 \%$ enzyme inhibition. Data were pooled and fitted to nonlinear regression model. Data are means of three replicates. ${ }^{2 /} \mathrm{CB}=\mathrm{cyhalofop}$ acid, $\mathrm{FA}=$ fenoxaprop acid, $\mathrm{SE}=$ sethoxydim, $\mathrm{TP}=$ tepraloxydim. ${ }^{3 /} \mathrm{SE}=$ standard error of the value. ${ }^{4 /}$ Approximate coefficient of determination of nonlinear models with a defined intercept calculated as pseudo $\mathrm{r}^{2}=1$ - (sums of squares of the regression/corrected total sums of squares). 5/ Probability level of significance of the nonlinear model. ${ }^{6 /} \mathrm{RF}=$ resistant factor $=\mathrm{EC}_{50}$ of resistant $/ \mathrm{EC}_{50}$ of susceptible biotype.

ACCase genes of other grass weeds (Figure 1). The nucleotide sequences of the $\mathrm{B}$ region for the resistant biotype differed from that of the susceptible one by a single nucleotide substitution (G/C), consequently yielding an Asp 2078 to Gly change in the resistant population.
The data from this work, confirmed the hypothesis that a target site mutation is the mechanism of resistance to herbicides in this ELEIN biotype from Brazil. Only recently the understanding of the mechanisms involved on ACCase inhibitors cross resistance was elucidated. So far, six variable amino acids in 


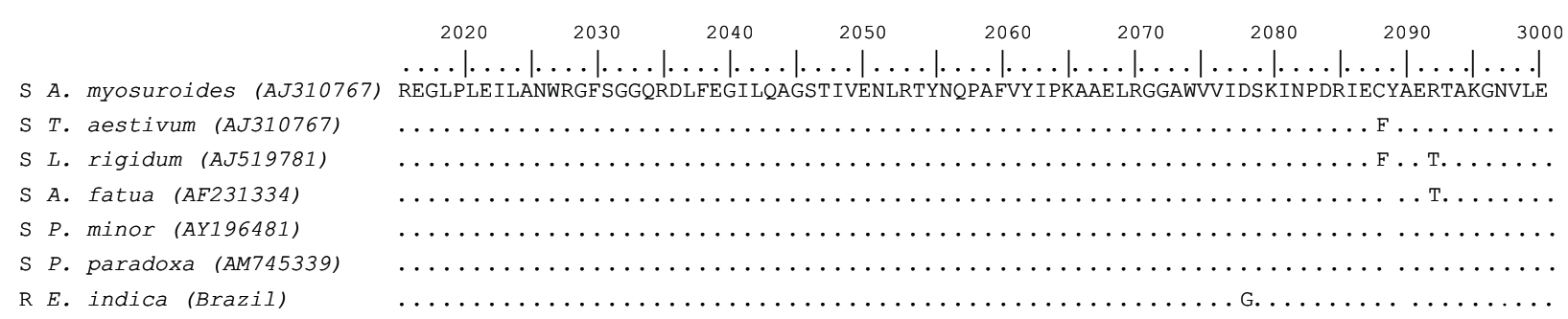

Figure 1 - Alignment of partial chloroplastic sequences from resistant (R) and susceptible (S) grasses. ACCase genes from the following species are presented: Alopecurus myosuroides, Triticum aestivum, Lolium rigidum, Avena fatua and Phalaris minor, P. paradoxa and Eleusine indica. Positions refer to the Alopecurus myosuroides ACCase gene (AJ310767).

the ACCase protein may confer different degrees of sensitivity to the herbicides because of difficulties in their access to and/or the fit inside the enzyme active site (Délye et al., 2005; Zhang \& Powles, 2006). Furthermore, the high level of resistance verified to sethoxydim is a strong indicator of target site-based resistance because this compound is not exposed to metabolism-based resistance (Moss et al., 2003). As expected, on the ACCase enzyme assay, the RF calculated for the $R$ biotype ranged between 11 and 94 (Table 3). These high values for the RF factors are strong evidence of a target site mechanism of resistance in the $E$. indica biotype from Mato Grosso, Brazil.

Further molecular studies have indicated an Asp-2078-Gly substitution in the $R$ population endowed resistance to both APP and CHD herbicides (Figure 1). The same mutation has been reported in other grass weeds (Délye et al., 2005; Liu et al., 2007; Yu et al., 2007; Hochberg et al., 2009) and endows resistance of these to ACCase-inhibitors.

It is probable that few grass herbicide options for the soybean crop in Brazil and lack of crop rotation may have aided the selection of target site mutations in E. indica, and consequent resistance to ACCase inhibitors. This complicates the design of adequate weed management strategies. Herbicides from alternative modes of action other than ACCase inhibitors would be recommended strategy to deal with the $E$. indica resistance. However, caution should be taken to avoid selection pressure from only one herbicide option, because worldwide there have been reported evolved resistant E. indica populations to glyphosate (Ng et al., 2003; Baerson et al., 2002; Kaundun et al., 2011), to metribuzin
(Brosnan et al., 2008), and to glufosinate and paraquat (Seng et al., 2010).

\section{ACKNOWLEDGEMENTS}

This work was supported by CAPES and CNPQ (Brazilian Research Agencies). To prof. T. Bauman (Purdue University) for helpful suggestions to an early draft of this paper.

\section{LITERATURE CITED}

BAERSON, S. R. et al. Glyphosate-resistant goosegrass: Identification of a mutation in the target enzyme 5enolpyruvylshikimate-3-phosphate synthase. Plant Physiol., v. 129, n. 6, p. 1265-1275, 2002.

BROSNAN, J. T.; NISHIMOTO, R. K.; DEFRANK, J. Metribuzin-Resistant Goosegrass (Eleusine indica) in Bermudagrass Turf. Weed Technol., v. 22, n. 4, p. 675-678, 2008.

De PRADO, R. et al. Resistance to acetyl CoA carboxylaseinhibiting herbicides in Lolium multiflorum. Weed Sci., v. 48, n. 3, p. 311-318, 2000.

DÉLYE, C. Weed resistance to acetyl coenzyme A carboxylase inhibitors: an update. Weed Sci., v. 53, n. 5, p. 728-746, 2005.

DÉLYE, C. et al. An isoleucine residue within the carboxyltransferase domain of multidomain acetyl-coenzyme A carboxylase is a major determinant of sensitivity to aryloxyphenoxypropionate but not to cyclohexanedione inhibitors. Plant Physiol., v. 132, n. 3, p. 1716-1723, 2003.

DÉLYE, C. et al. Molecular basis for sensitivity to acetylcoenzyme a carboxylase inhibitors in black-grass. Plant Physiol., v. 137, n. 3, p. 794-806, 2005.

FRANS, R. et al. Experimental design and techniques for measuring and analyzing plant responses to weed control practices. In: CAMPER, N. D. Research methods in weed science. 3.ed. Champaign: WSSA, 1986. p. 29-46. 
GHEREKHLOO, J.; OSUNA, M. D.; DE PRADO, R. Biochemical and molecular basis of resistance to ACCaseinhibiting herbicides in Iranian Phalaris minor populations. Weed Res., 2012. in press.

HOCHBERG, O.; SIBONY, M.; RUBIN, B. The response of ACCase-resistant Phalaris paradoxa populations involves two different target site mutations. Weed Res., v. 49, n. 4, p. 37-46, 2009.

KAUNDUN, S. S. An aspartate to glycine change in the carboxyl transferase domain of acetyl CoA carboxylase and non-target-site mechanism(s) confer resistance to ACCase inhibitor herbicides in a Lolium multiflorum population. Pest Manag. Sci., v. 66, n. 11, p. 1249-1256, 2010.

KAUNDUN, S. S. et al. A Novel P106L mutation in EPSPS and an unknown mechanism(s) act additively to confer resistance to glyphosate in a South African Lolium rigidum population. J. Agric. Food Chem., v. 59, n. 7, p. 3227-3233, 2011.

KISSMAN, K. G.; GROTH, D. Plantas infestantes e nocivas. São Paulo: BASF, 1991. 798 p.

LIU, W. J. et al. Single-site mutations in the carboxyltransferase domain of plastid acetyl-CoA carboxylase confer resistance to grass-specific herbicides. Proc. Nat. Acad. Sci., v. 104, n. 9, p. 3627-3632, 2007.

MOSS, S. R. et al. Characterisation of target-site resistance to ACCase-inhibiting herbicides in the weed Alopecurus myosuroides (black-grass). Pest Manag. Sci., v. 59, n. 1, p. 190-201, 2003.
NG, C. H. et al. Gene polymorphisms in glyphosate-resistant and -susceptible biotypes of Eleusine indica from Malaysia. Weed Res., v. 43, n. 2, p. 108-115, 2003.

POWLES, S. B.; YU, Q. Evolution in Action: Plants Resistant to Herbicides. Ann. Rev. Plant Biol., v. 61, n. 1, p. 317-347, 2010.

SENG, C. T. et al. Initial report of glufosinate and paraquat multiple resistance that evolved in a biotype of goosegrass (Eleusine indica) in Malaysia. Weed Biol. Manag., v. 10, n. 4, p. 229-233, 2010.

VIDAL, R. A. et al. Resistência de Eleusine indica aos inibidores de ACCase. Planta Daninha, v. 24, n. 1, p. 163-171, 2006.

WHITE, G. M.; MOSS, S. R.; KARP, A. Differences in the molecular basis of resistance to the cyclohexanedione herbicide sethoxydim in Lolium multiflorum. Weed Res., v. 45, n. 6, p. 440-448, 2005.

YU, Q. et al. Diversity of acetyl-coenzyme a carboxylase mutations in resistant Lolium populations: Evaluation using clethodim. Plant Physiol., v. 145, n. 2, p. 547-558, 2007.

XIA, G. J.; LI, X. L.; YANG, H. W. Preliminary study on competition between soyabean and goosegrass. Soybean Sci., v. 16, n. 4, p. 352-354, 1997.

ZHANG, X. Q.; POWLES, S. B. Six amino acid substitutions in the carboxyl-transferase domain of the plastidic acetyl-CoA carboxylase gene are linked with resistance to herbicides in a Lolium rigidum population. New Phytol., v. 172, n. 4, p. 636-645, 2006. 